OPEN ACCESS

Edited by:

Simone Brogi,

University of Siena, Italy

Reviewed by:

Lisa Moni,

Università di Genova, Italy

Xiao-Yu Hu,

Nanjing University, China

Guzman Gil-Ramirez,

University of Lincoln, United Kingdom

Peter Timmerman,

Pepscan, Netherlands

*Correspondence:

Shafida Abd Hamid

shafida@iium.edu.my

Specialty section:

This article was submitted to Medicinal and Pharmaceutical

Chemistry,

a section of the journa

Frontiers in Chemistry

Received: 24 January 2018

Accepted: 23 May 2018

Published: 12 June 2018

Citation:

Ali Y, Muhamad Bunnori N, Susanti $D$ Muhammad Alhassan A and Abd Hamid S (2018) Synthesis, in-Vitro and in Silico Studies of Azo-Based Calix[4]arenes as Antibacterial Agent and Neuraminidase Inhibitor: A New Look Into an Old Scaffold.

Front. Chem. 6:210.

doi: 10.3389/fchem.2018.00210

\section{Synthesis, in-Vitro and in Silico Studies of Azo-Based Calix[4]arenes as Antibacterial Agent and Neuraminidase Inhibitor: A New Look Into an Old Scaffold}

\author{
Yousaf Ali ${ }^{1,2}$, Noraslinda Muhamad Bunnori ${ }^{2}$, Deny Susanti ${ }^{2}$, \\ Alhassan Muhammad Alhassan ${ }^{3}$ and Shafida Abd Hamid ${ }^{2 *}$ \\ ${ }^{1}$ Department of Chemistry, Sarhad University of Science and Information Technology, Peshawar, Pakistan, ${ }^{2}$ Kulliyyah of \\ Science, International Islamic University Malaysia, Kuantan, Malaysia, ${ }^{3}$ Kulliyah of Pharmacy, International Islamic University \\ Malaysia, Kuantan, Malaysia
}

Calixarene derivatives are reported as potential therapeutic agents. Azo derivatives of calixarenes have not been given much consideration to explore their biomedical applications. In the present study, some azo-based derivatives of calix[4]arene were synthesized and characterized and their antibacterial and antiviral potentials were studied. The mono azo products of sulphanilamide, sulfaguanidine and 2-methyl-4-aminobenzoic acid showed good activity against bacterial strains with minimum inhibition concentration values ranging from 0.97 to $62.5 \mu \mathrm{g} / \mathrm{mL}$. For mono azo products, the diazotized salt was applied as a limiting reagent. The use of calix[4]arene and sodium acetate trihydrate in 1:3 (molar ratio) helped in partial substitution. Molecular docking was performed to see the interaction of the designed compounds with two bacterial and one viral (neuraminidase) receptor. Some of the derivatives showed good interaction with the active site of bacterial and neuraminidase enzymes through hydrogen, hydrophobic and pi-pi interactions, and could inhibit the activity of the selected enzymes.

Keywords: calix[4]arenes, azo calix[4]arenes, antibacterial activity, docking, neuraminidase inhibition

\section{INTRODUCTION}

Calixarenes, known as the third generation of supramolecules, are cyclic oligomers that are synthesized from phenol and formaldehyde (Shinkai, 1993). Calixarene derivatives have been described as metal extractants, ions transporters, electrode ionophores optical sensors (Vicens and Böhmer, 2012; Deska et al., 2015), while various others have been suggested as potential drug candidates (Yousaf et al., 2015). They showed antimicrobial, antidiabetic, antitubercular, anticancer and anti-HIV activities (Nimse and Kim, 2013; Tauran et al., 2015). The cup-shaped structure of calixarene also provides suitable architecture to be used as drug delivery vehicle (Mo et al., 2016).

Calixarene derivatives containing azo moiety $(-\mathrm{N}=\mathrm{N}-)$ are synthesized by insertion of nitrogen at the para position(s) of de-butylated calixarene or by incorporating phenyl azo moieties at lower rim via the phenolic hydroxy group (Deligöz and Ercan, 2002; Sliwa and Deska, 2011). The four para positions of calix[4] arene are equally available for nitrogen insertion to give the tetrakis azo product. Due to the symmetry of the calix[4]arene, it is quite a challenge to introduce 
functional groups in a selective fashion among the four para positions (Vicens et al., 2007). Selective diazotization at the upper rim is mostly reported after lower rim modification such as alkylation, acylation etc. (Karakuş and Deligöz, 2015). Steric hindrance of the coupling agent and incompletion of reaction have also been reported as the reasons for partial substitution (Ramanjaneyulu et al., 2010). To obtain mono-( $p$-substituted phenyl)azo calix[4]arene in quantitative yield, Jin et al. (2002) used isoamyl nitrite in $\mathrm{EtONa} / \mathrm{EtOH}$ for the diazotization of aniline and the reaction was carried out in the presence of carbon dioxide gas in THF.

Azo calixarenes are mainly reported for detection of different ionophores and extraction of transition metal cations (Elçin et al., 2016). Some azo calixarenes also showed coloring properties (Tang et al., 2015). However, the drug-like potential of azo calixarenes has not been given much consideration. Azo compounds of pyrimidine (Gulcan et al., 2014; Shaikh and Meshram, 2015) and other therapeutically recognized classes of organic compounds, such as enamines, pyrazole, thiazole, and triazole have shown excellent antimicrobial activities (Rizk et al., 2015; Sahoo et al., 2015). It has been reported that the introduction of azo group has improved more than $60 \%$ of the antibacterial activities of certain molecules (Mkpenie et al., 2008). It was assumed that azo calix[4]arenes will also show better antimicrobial properties. Some upper rimmodified azo calix[4] arenes were synthesized (Figure 1) and their activity against selected strains of bacteria and fungi was evaluated. An optimized protocol was applied to obtain mono azo calix[4] arene in reasonable yield. Molecular docking study was performed to see the binding interaction and inhibition potential of the selected compounds toward the microbial enzymes. In addition, docking against neuraminidase receptor was also included as a theoretical model of antiviral study.

\section{MATERIALS AND METHODS}

\section{Synthesis}

All the chemicals and reagents were supplied by Acros Organics, Merck, Sigma-Aldrich, or QReC and used without further purification. Melting point analysis was carried out by open capillaries using Electrothermal melting point apparatus (UK). ${ }^{1} \mathrm{H}-\mathrm{NMR}$ and ${ }^{13} \mathrm{C}-\mathrm{NMR}$ spectra of the compounds were recorded on BRUKER AVANCE III ULTRASHIELD PLUS spectrometer at 500 and $125 \mathrm{MHz}$, respectively (Supporting Information). Deuterated solvents of different choices based on the solubility of compounds were used. Chemical shifts are given in $\delta$ scale (ppm) and tetramethylsilane (TMS) was used as internal reference. Nominal mass spectra of selected compounds were analyzed on LcQ Finnigan MAT mass spectrometer with atmospheric pressure chemical ionization (APCI) as a probe.

\section{5,26,27,28-Tetrahydroxyclaix[4]arene}

$1 \mathrm{~g}$ of $p$-tert-butylcalix[4]arene $(1.54 \mathrm{mmol})$ and $0.8 \mathrm{~g}$ of phenol $(8.49 \mathrm{mmol})$ were stirred in dry toluene $(10.5 \mathrm{~mL})$ under nitrogen for $45 \mathrm{~min}$ at $90^{\circ} \mathrm{C}$. The suspension was allowed to cool and $\mathrm{AlCl}_{3}(1.1 \mathrm{~g}, 8.23 \mathrm{mmol})$ was added at $5-10^{\circ} \mathrm{C}$ while stirring. After $12 \mathrm{~h}$ stirring at room temperature, $2 \mathrm{M} \mathrm{HCl}$ $(6.5 \mathrm{~mL})$ was added to the mixture and stirring was continued for further $30 \mathrm{~min}$. The organic layer was separated and the excess toluene was evaporated by rotary evaporator. Chloroform $(4.5 \mathrm{~mL})$ was added to the flask and refluxed for $30 \mathrm{~min}$ to give a clear solution which was allowed to cool. The product precipitated after addition of $\mathrm{MeOH}(6.5 \mathrm{~mL})$. Recrystallization from $\mathrm{CHCl}_{3} / \mathrm{MeOH}$ (6:2) gave white powder product. Yield (45\%), mp 312-313 ${ }^{\circ} \mathrm{C}$; ${ }^{1} \mathrm{H}$ NMR (500 $\left.\mathrm{MHz}, \mathrm{CDCl}_{3}\right) \delta(\mathrm{ppm})$ : $3.50\left(4 \mathrm{H}, \mathrm{bs}, \mathrm{Ar}-\mathrm{CH}_{2}-\mathrm{Ar}\right), 4.32\left(4 \mathrm{H}, \mathrm{bs}, \mathrm{Ar}-\mathrm{CH}_{2}-\mathrm{Ar}\right), 6.71(4 \mathrm{H}$, $\mathrm{t}, \mathrm{Ar}-\mathrm{H}, J=8.0 \mathrm{~Hz}), 7.04(8 \mathrm{H}, \mathrm{d}, \mathrm{Ar}-\mathrm{H}, J=12.0 \mathrm{~Hz}), 10.2(\mathrm{~s}$, $4 \mathrm{H}, \mathrm{Ar}-\mathrm{OH}) ;{ }^{13} \mathrm{C}-\mathrm{NMR}\left(125 \mathrm{MHz}, \mathrm{CDCl}_{3}\right) \delta: 148.8,129.0,128.2$, 122.3, 31.7 .

\section{Synthesis of N-(diaminomethylidene)-4-[(E)-(4- Hydroxyphenyl)diazenyl] benzenesulfonamide (SPh)}

A solution of sodium nitrite $(0.17 \mathrm{~g}, 7.3 \mathrm{mmol})$ in water $(2 \mathrm{~mL})$ was slowly added to an acidified solution of sulfaguanidine $(0.64 \mathrm{~g}, 3 \mathrm{mmol})$ in water/acetone mixture $(12 \mathrm{~mL}, 2: 1)$ at $0^{\circ} \mathrm{C}$. The resulting diazonium salt solution was gently added to an ice-cold solution of phenol $(0.29 \mathrm{~g}, 3 \mathrm{mmol}), \mathrm{NaOH}(0.34 \mathrm{~g}, 8.5$ $\mathrm{mmol})$ and $\mathrm{Na}_{2} \mathrm{CO}_{3}(0.9 \mathrm{~g}, 8.5 \mathrm{mmol})$ in $10 \mathrm{~mL}$ water and the mixture was stirred for $2 \mathrm{~h}$. Then $50 \mathrm{~mL}$ water was added and the mixture was allowed to stand for $2 \mathrm{~h}$. The yellow precipitate was filtered, recrystallized from EtOAc and purified by column chromatography $\left(\mathrm{CHCl}_{3} / \mathrm{MeOH}, 4: 1\right)$. Yield (67\%), mp 256$258^{\circ} \mathrm{C}$; IR (KBr) $v$ : $1541.5 \mathrm{~cm}^{-1}(-\mathrm{N}=\mathrm{N}),{ }^{1} \mathrm{H}-\mathrm{NMR}(500 \mathrm{MHz}$, DMSO-d $\left._{6}\right) \delta(\mathrm{ppm}): 6.77\left(4 \mathrm{H}, \mathrm{bs}, \mathrm{C}-\mathrm{NH}_{2}\right), 6.9(2 \mathrm{H}, \mathrm{d}, \mathrm{Ar}-\mathrm{H}$, $J=8.0 \mathrm{~Hz}), 7.8(2 \mathrm{H}, \mathrm{d}, \mathrm{Ar}-\mathrm{H}, J=10.0 \mathrm{~Hz}), 7.9(4 \mathrm{H}, \mathrm{d}, \mathrm{Ar}-\mathrm{H}$, $J=8 \mathrm{~Hz}),{ }^{13} \mathrm{C}-\mathrm{NMR}\left(125 \mathrm{MHz}\right.$, DMSO- $\left.d_{6}\right) \delta: 161.6,158.1,153.2$, $145.1,126.8,125.2,116.0$.

\section{5,26,27,28-Tetrahydroxy-5- (sulfaguanidine)azocalix[4]arene (SGC)}

A solution of diazonium salt, prepared from sulfaguanidine $(0.2 \mathrm{~g}, 1 \mathrm{mmol})$, sodium nitrite $(0.069 \mathrm{~g}, 1 \mathrm{mmol})$ and conc. $\mathrm{HCl}(2 \mathrm{~mL})$ in $10 \mathrm{~mL}$ water/acetone (1:2) mixture, was added to an ice-cold solution of calix[4]arene $(0.85 \mathrm{~g}, 2 \mathrm{mmol})$ and sodium acetate trihydrate $(0.68 \mathrm{~g}, 5 \mathrm{mmol})$ in $\mathrm{H}_{2} \mathrm{O} / \mathrm{DMF}(20 \mathrm{~mL}$, $5: 8, \mathrm{v} / \mathrm{v})$ giving yellowish orange suspension. After standing for $2 \mathrm{~h}$ at room temperature, the suspension was acidified with aqueous $\mathrm{HCl}(50 \mathrm{~mL}, 0.25 \%)$. The dried solid mass was dissolved in dichloromethane and purified by column chromatography (Hex/EtOAc, 2:3). Yield (55\%), mp $263-65^{\circ} \mathrm{C}$; IR (KBr) $v$ : $1,541 \mathrm{~cm}^{-1}(-\mathrm{N}=\mathrm{N}-),{ }^{1} \mathrm{H}-\mathrm{NMR}\left(500 \mathrm{MHz}, \mathrm{CDCl}_{3}\right) \delta(\mathrm{ppm})$ : $3.55\left(4 \mathrm{H}\right.$, bs, Ar- $\left.\mathrm{CH}_{2}-\mathrm{Ar}\right), 4.28\left(4 \mathrm{H}, \mathrm{bs}, \mathrm{Ar}-\mathrm{CH}_{2}-\mathrm{Ar}\right), 6.5(4 \mathrm{H}$, bs, C-NH2 $), 6.71(3 \mathrm{H}, \mathrm{t}, \mathrm{Ar}-\mathrm{H}, J=7.5 \mathrm{~Hz}), 7.04(6 \mathrm{H}, \mathrm{d}$, Ar-H, J $=8 \mathrm{~Hz}), 7.6(2 \mathrm{H}, \mathrm{s}, \operatorname{Ar}-\mathrm{H}($ calix $)), 7.8(4 \mathrm{H}, \mathrm{d}, \mathrm{Ar}-$ $\mathrm{H}, J=8.5 \mathrm{~Hz}), 7.9(4 \mathrm{H}, \mathrm{d}, \mathrm{Ar}-\mathrm{H}, J=8.5 \mathrm{~Hz}) ;{ }^{13} \mathrm{C}-\mathrm{NMR}$ $\left(125 \mathrm{MHz}, \mathrm{DMSO}-d_{6}\right) \delta: 159.8,158.0,153.5,149.3,144.9$, $144.5,130.6,128.5,126.6,124.0,122.0,121.1,30.6,30.5$; ESIMS $m / z$ calcd. for $\left[\mathrm{C}_{35} \mathrm{H}_{31} \mathrm{~N}_{5} \mathrm{O}_{6} \mathrm{~S}\right]^{+} 649.20$; found 648.30 $[\mathrm{M}+\mathrm{H}]^{+}$. 


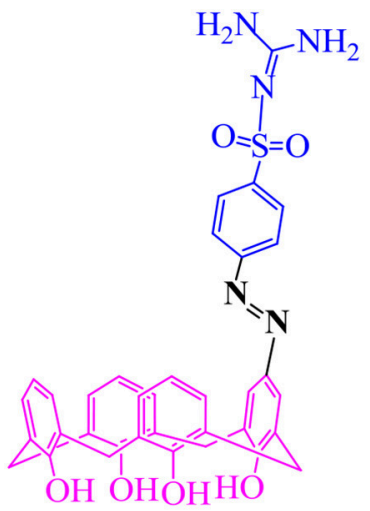

SGC

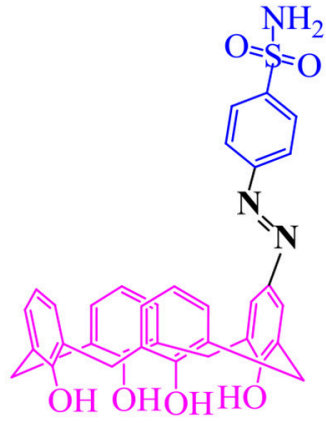

SCM

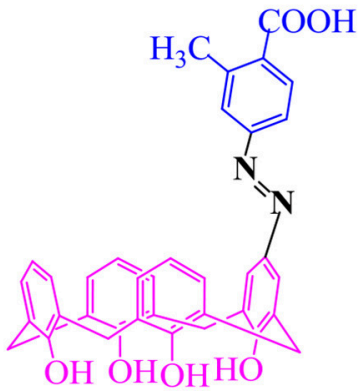

COX<smiles>NC(N)=NS(=O)(=O)c1ccc(N=Nc2ccc(O)cc2)cc1</smiles><smiles>Oc1c2cc(N=Nc3cccc(C(F)(F)F)c3)cc1C(N=Nc1cccc(C(F)(F)F)c1)=Cc1c(O)c(c(O)c(O)c1N=Nc1cccc(C(F)(F)F)c1)C2</smiles>

STF

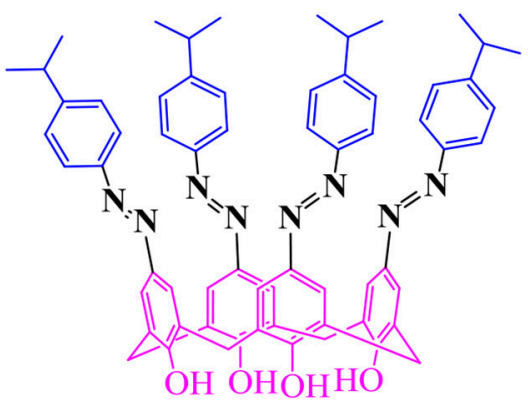

ISO

FIGURE 1 | Chemical structures of synthesized azo compounds.

\section{5,26,27,28-Tetrahydroxy-5-(4- sulphonylaminophenyl)azocalix[4]arene (SCM)}

Compound SCM was prepared as described above for compound SGC. The diazonium salt of 4-aminobenzenesulfonamide $(0.172 \mathrm{~g}, 1 \mathrm{mmol})$, was added to an ice-cold solution of calix[4]arene $(0.85 \mathrm{~g}, 2 \mathrm{mmol})$ and sodium acetate trihydrate ( $0.68 \mathrm{~g}, 5 \mathrm{mmol})$ in $\mathrm{H}_{2} \mathrm{O} / \mathrm{DMF}(20 \mathrm{~mL}, 5: 8$, v/v). After standing for $2 \mathrm{hr}$ at room temperature, the suspension (red color) was acidified with aqueous $\mathrm{HCl}(50 \mathrm{~mL}, 0.25 \%)$ to give the orange solid product, which was filtered, washed with distilled water and dried over $\mathrm{MgSO}_{4}$. The product was purified by column chromatography $\left(\mathrm{CHCl}_{3} / \mathrm{MeOH}, 7: 1\right)$. Yield (67\%), >200 mp ${ }^{\circ} \mathrm{C}$; IR $(\mathrm{KBr}) v: 1,590 \mathrm{~cm}^{-1}(-\mathrm{N}=\mathrm{N}-),{ }^{1} \mathrm{H}-\mathrm{NMR}(500 \mathrm{MHz}$, $\left.\mathrm{CDCl}_{3}\right) \delta(\mathrm{ppm}): 3.56$ (bs, Ar- $\left.\left.\mathrm{CH}_{2}-\mathrm{Ar}\right) ;\right), 4.29$ (4H, bs, Ar$\left.\mathrm{CH}_{2}-\mathrm{Ar}\right), 4.89(2 \mathrm{H}, \mathrm{s}, \mathrm{OH}) 6.9\left(4 \mathrm{H}, \mathrm{bs}, \mathrm{C}-\mathrm{NH}_{2}\right), 6.74(3 \mathrm{H}, \mathrm{m}$, Ar-H), 7.1 (6H, m, Ar-H), 7.73 (2H, s, Ar-H(calix)), $7.9(4 \mathrm{H}$, d, Ar-H, $J=8.4 \mathrm{~Hz}), 8.0(4 \mathrm{H}, \mathrm{d}, \mathrm{Ar}-\mathrm{H}, J=10.6 \mathrm{~Hz}), 10.19$ $(4 \mathrm{H}, \mathrm{s}, \mathrm{OH}) ;{ }^{13} \mathrm{C}-\mathrm{NMR}\left(125 \mathrm{MHz}, \mathrm{DMSO}-d_{6}\right) \delta: 150.2,129.4$, $129.2,129.0,128.6,127.2,127.5,122.5,121.4,121.3,31.2,31.1$; ESI-MS $\mathrm{m} / \mathrm{z}$ calcd. for $\left[\mathrm{C}_{34} \mathrm{H}_{29} \mathrm{~N}_{3} \mathrm{O}_{6} \mathrm{~S}\right]^{+}$607.18; found 606.2 $[\mathrm{M}-\mathrm{H}]^{+}$.

\section{5,26,27,28-Tetrahydroxy-5-((4-corboxy-3- methyl)phenyl)azocalix[4]arene (COX)}

Compound COX was prepared as described above for compound SGC. The diazonium salt, of 4-amino-2-methylbenzoic acid $(0.15 \mathrm{~g}, 1 \mathrm{mmol})$ was added to an ice-cold solution of calix[4]arene $(0.85 \mathrm{~g}, 2 \mathrm{mmol})$ and sodium acetate trihydrate (0.68 g, $5 \mathrm{mmol})$ in $\mathrm{H}_{2} \mathrm{O} / \mathrm{DMF}(20 \mathrm{~mL}, 5: 8, \mathrm{v} / \mathrm{v})$. The product was purified by preparative chromatography (Hex/EtOAc, 2:3). Yield (48\%), mp 260-62 ${ }^{\circ}$; IR (KBr) $v: 1591 \mathrm{~cm}^{-1}(-\mathrm{N}=\mathrm{N}-),{ }^{1} \mathrm{H}-\mathrm{NMR}$ $(500 \mathrm{MHz}, \mathrm{MeOD}) \delta(\mathrm{ppm}): 3.30\left(8 \mathrm{H}, \mathrm{s}, \mathrm{Ar}-\mathrm{CH}_{2}-\mathrm{Ar}\right), 6.58(3 \mathrm{H}, \mathrm{t}$, Ar-H, $J=7.5 \mathrm{~Hz}), 6.96(1 \mathrm{H}, \mathrm{d}, \mathrm{Ar}-\mathrm{H}, J=7.5 \mathrm{~Hz}), 7.03(6 \mathrm{H}, \mathrm{m}, \mathrm{Ar}-$ $\mathrm{H}, J=7.5 \mathrm{~Hz}), 7.54(1 \mathrm{H}, \mathrm{d}, \mathrm{Ar}-\mathrm{H}, J=8.1 \mathrm{~Hz}), 7.58(1 \mathrm{H}, \mathrm{s}, \mathrm{Ar}-\mathrm{H})$, 7.65 (2H, s, Ar-H): ${ }^{13} \mathrm{C}-\mathrm{NMR}(125 \mathrm{MHz}, \mathrm{MeOD}) \delta: 154.5,153.5$, $152.4,138.6,129.4,125.3,121.3,120.09,43.1,32.8,21.2$; ESI-MS $\mathrm{m} / z$ calcd. for $\left[\mathrm{C}_{36} \mathrm{H}_{30} \mathrm{~N}_{2} \mathrm{O}_{6}\right]^{+} 586.21$; found $585.2[\mathrm{M}-\mathrm{H}]^{+}$.

\section{5,26,27,28-Tetrahydroxy-5,11,17,23-tetrakis(3- trifluoromethyl)phenyl) azocalix[4]arene (STF)}

A solution of diazonium chloride, prepared from 3(trifluoro)methylaniline $(1.28 \mathrm{~g}, 8 \mathrm{mmol})$, sodium nitrite 
(1.1 g, $16 \mathrm{mmol})$ and conc. $\mathrm{HCl}(2 \mathrm{~mL})$ in water $(5 \mathrm{~mL})$, was added dropwise to a cold $\left(5^{\circ} \mathrm{C}\right)$ solution of calix[4] arene $(1.7 \mathrm{~g}$, $4 \mathrm{mmol})$ and sodium acetate trihydrate $(6.8 \mathrm{~g}, 50 \mathrm{mmol})$ in $\mathrm{H}_{2} \mathrm{O} / \mathrm{DMF}$ ( $25 \mathrm{~mL}, 5: 8 \mathrm{v} / \mathrm{v}$ ) to give an orange suspension. The suspension was acidified with aqueous $\mathrm{HCl}(80 \mathrm{~mL}, 0.25 \%)$ and the mixture was then warmed to $60^{\circ} \mathrm{C}$ for $30 \mathrm{~min}$. Then $50 \mathrm{~mL}$ EtOAc was added to the mixture at room temperature. The crude product gave a pale brown solid, which was filtered and washed with EtOAc and purified by column chromatography (Hex/EtOAc, 1:3). Yield (75\%), mp $>280^{\circ} \mathrm{C}$; ${ }^{1} \mathrm{H}-\mathrm{NMR}(500$ $\left.\mathrm{MHz}, \mathrm{CDCl}_{3}\right) \delta$ (ppm): 3.87 (4H, bs, Ar- $\left.\mathrm{CH}_{2}-\mathrm{Ar}\right), 4.41$ (4H,bs, $\left.4 \mathrm{H}, \mathrm{Ar}-\mathrm{CH}_{2}-\mathrm{Ar}\right), 7.59(6 \mathrm{H}, \mathrm{t}, \mathrm{Ar}-\mathrm{H}, J=7.7 \mathrm{~Hz}), 7.67(1 \mathrm{H}$, d, Ar-H(calix), J = $7.65 \mathrm{~Hz}), 7.85(4 \mathrm{H}, \mathrm{s}, \operatorname{Ar}-\mathrm{H}), 8.00(2 \mathrm{H}$, $\mathrm{d}, \mathrm{Ar}-\mathrm{H}, J=8.0 \mathrm{~Hz}), 8.10(4 \mathrm{H}, \mathrm{s}, \mathrm{Ar}-\mathrm{H}), 10.28(4 \mathrm{H}, \mathrm{s}, \mathrm{OH})$; ${ }^{13} \mathrm{C}-\mathrm{NMR}\left(125 \mathrm{MHz}, \mathrm{DMSO}-\mathrm{d}_{6}\right) \delta: 159.1,152.2,144.5,130.5$, $130.2,129.8,126.06,122.7,117.6,31.52$; ESI-MS $\mathrm{m} / z$ calcd. for $\left[\mathrm{C}_{56} \mathrm{H}_{36} \mathrm{~F}_{12} \mathrm{~N}_{8} \mathrm{O}_{4}\right]^{+}$1112.27; found 1113.1 $[\mathrm{M}+\mathrm{H}]^{+}$.

\section{5,26,27,28-Tetrahydroxy-5,11,17,23-tetra(4- isopropylphenyl)azocalix[4]arene (ISO)}

Compound ISO was prepared as described for compound CTF by adding diazonium salt of isopropylaniline $(0.48 \mathrm{~g}, 3.5 \mathrm{mmol})$ to an ice cold $\left(5^{\circ} \mathrm{C}\right)$ solution of calix[4] arene $(0.212 \mathrm{~g}, 0.5$ $\mathrm{mmol})$ and sodium acetate trihydrate $(2.38 \mathrm{~g}, 17.5 \mathrm{mmol})$ in $\mathrm{H}_{2} \mathrm{O} / \mathrm{DMF}(25 \mathrm{~mL}, 5: 8, \mathrm{v} / \mathrm{v})$ to give gray suspension. The crude product gave a pale brown solid which was purified by coloumn chromatography (Hex/EtOAc, 2:1). Yield (72\%), mp $>280^{\circ} \mathrm{C}$; IR (KBr) v: $1,469 \mathrm{~cm}^{-1}(-\mathrm{N}=\mathrm{N}-),{ }^{1} \mathrm{H}-\mathrm{NMR}\left(500 \mathrm{MHz}, \mathrm{CDCl}_{3}\right)$ $\delta(\mathrm{ppm}): 1.25\left(24 \mathrm{H}, \mathrm{d}, \mathrm{C}-\left(\mathrm{CH}_{3}\right)_{2}, J=7.0 \mathrm{~Hz}\right), 2.85(4 \mathrm{H}, \mathrm{q}$, $\mathrm{CH}\left(\mathrm{CH}_{3}\right)_{2}, 3.84$ (bs, Ar- $\left.\mathrm{CH}_{2}-\mathrm{Ar}\right) ;$ ), 4.37 (bs, $4 \mathrm{H}, \mathrm{Ar}-\mathrm{CH}_{2}-\mathrm{Ar}$ ), $7.30(4 \mathrm{H}, \mathrm{d}, \mathrm{Ar}-\mathrm{H}, J=8.35 \mathrm{~Hz}), 7.75(4 \mathrm{H}, \mathrm{d}, \mathrm{Ar}-\mathrm{H}, J=8.4 \mathrm{~Hz})$, $7.78\left(8 \mathrm{H}, \mathrm{s}, \mathrm{Ar}-\mathrm{H}\right.$ (calix), $10.25(4 \mathrm{H}, \mathrm{s}, \mathrm{OH}),{ }^{13} \mathrm{C}-\mathrm{NMR}(125 \mathrm{MHz}$, $\left.\mathrm{CDCl}_{3}\right) \delta: 151.85,151.1,147.8,128.2,127.02,124.2,122.6,34.09$, 31.8, 23.8. ESI-MS $m / z$ calcd. for $\left[\mathrm{C}_{64} \mathrm{H}_{64} \mathrm{~N}_{8} \mathrm{O}_{4}\right]^{+} 1008.51$; found $1009.3[\mathrm{M}+\mathrm{H}]^{+}$.

\section{In Vitro Antibacterial Assay}

The MIC values of the synthesized azo calix[4]arenes were determined using micro broth dilution method (Balouiri et al., 2016). Briefly, morphologically identical 3-4 colonies of cultured bacteria were taken from agar plates and suspended in a 4$5 \mathrm{~mL}$ of Mueller-Hinton broth (MHB). The suspension was incubated at $37^{\circ} \mathrm{C}$ for $2-6 \mathrm{~h}$ and then diluted to adjust the size of inoculum to the $0.5 \mathrm{MacF}$ arland standard turbidity, $5 \times 10^{5}$ $5 \times 10^{6} \mathrm{CFU} / \mathrm{mL}$ (Colony Forming Unit). The stock solutions of the compounds were serially diluted to obtain $125,62.5,31.2$, $15.6,7.8,3.9,1.9$, and $0.97 \mu \mathrm{g} \mathrm{mL}^{-1}$ concentrations. An equal volume of bacterial inoculum was added to each well containing $0.05 \mathrm{~mL}$ of compound's serial dilutions. After incubation for 20$24 \mathrm{~h}$ at $37^{\circ} \mathrm{C}$, MIC was determined with micro plate reader as the lowest concentration of tested compound with absorbance that was comparable with the control/reference wells. Wells without inoculum or broth with only the drug were used as negative control. Gentamycin/chloramphenicol and bacteria-free solvent were used as a positive and negative control, respectively. Nystatin was used as reference drug for antifungal study. The
$\mathrm{MBC}$ was determined by culturing the contents of well exhibited no growth onto agar plates. The plates were incubated at $35^{\circ} \mathrm{C}$ for $24 \mathrm{~h}$. The $\mathrm{MBC}$ was considered as the lowest concentration of compound required to kill (99.9\%) of the tested microbes. The experiments were performed in triplicate and repeated three times with similar results.

\section{Docking Procedure}

Docking was performed by Autodock4.2. The crystal structures of receptors (PDB IDs: 4CJN, 1CEF and 3TI6) were retrieved from the Protein Data Bank (http://www.rcsb.org/pdb). The heteroatoms and water molecules were removed from protein. The PDB file of the receptor was added hydrogen bonds and the Gasteiger charge. Autogrid was used to obtain pre-calculated grid maps and the default optimization parameters were used (a maximum number of 250,000 energy evaluations and a maximum number of generations of 27,000), except the number of GA runs was increased to 30-50. The grid box used for specifying the search space was centered on the active site of the receptor with a default grid point spacing of $0.375 \AA$. To get more stable configuration, the energy of ligands was minimized to get more stable configuration. The docking result is presented in terms of binding energy (B.E) values given in $\mathrm{kcal} / \mathrm{mol}$ and inhibition constant $(\mathrm{Ki})$ in micro molar $(\mu \mathrm{M})$. The pose/conformation with the lowest B.E and the appropriate cluster was considered for further analysis and visualization. The molecular visualization of the docked complexes was performed using the Accelrys Discovery Studio 2016.

\section{RESULTS AND DISCUSSION}

\section{Chemistry}

Tetrahydrocalix[4]arene was synthesized following the general procedure (Gutsche et al., 1985; Gutsche and Iqbal, 1990). Usually, molecules with small size and low molecular weight are preferred in drug designing process (Schneider, 2000-2013). Mono azo products have low molecular weight and small size, and hence considered more close to the Lipinski Rule of 5. These factors are usually considered in drug designing process. The desired mono azo products were synthesized in reasonable yield according to the reported procedure (Morita et al., 1992; Elçin et al., 2013) with slight modification. The diazotized salt was applied as a limiting reagent and added to the basic solution of calix[4] arene at once instead of slow addition. Calix[4]arene and sodium acetate trihydrate were used in 1:3 (molar ratio) rather than $1: 15$. The latter is commonly practized by other researchers for the synthesis of the tetrakis azo product of calix[4]arene (Elçin et al., 2013). The reactions were stopped immediately (2-3 min) after addition of diazonium salt in all of the compounds, except in the case where tetra- product was desired. The combined effect of these three conditions resulted in mono azo calix[4] arene as the main product. The only disadvantage of selective diazotization by this method was an excess of unreacted calix[4] arene left after completion of the reaction, as underlined by other researchers as well (Chawla et al., 2006). However, the starting material was easily recovered by recrystallization or column chromatography. The use of weak catalyst like CsF was usually favored for 
mono alkylation of calix[4] arene at lower rim (Groenen et al., 1991). The same catalyst was used for upper rim modification replacing sodium acetate trihydrate that gave comparable result in producing a mono azo product of sulfanilamide.

Three mono azo calix[4]renes incorporating sulfaguanidine (SGC), sulphanilamide (SCM) and 2-methyl-4-amino benzoic acid (COX) moieties were synthesized (Figure 1) and the products were obtained in reasonable yield (40-65\%). Taking calix[4] arene and sodium acetate trihydrate in 1:3 (molar ratio) might have a role in partial substitution giving mono azo product. This may be due to the formation of monoanion of the calix[4]arene when the weak base removed only a single proton from the calix[4] arene. The ${ }^{1} \mathrm{H}-\mathrm{NMR}$ spectrum of monosubstituted products showed a doublet at $\sim 7.01$ and a triplet at $\sim 6.9 \mathrm{ppm}$ for ortho and para hydrogens of phenolic rings of calix[4] arene, respectively. The singlet at $\sim 7.5-7.9 \mathrm{ppm}$ indicates that para position of one phenol ring of calix[4]arene was substituted by the azo moiety. The bridging methylene peaks appeared at $\sim 3.52$ and $\sim 4.21$ ppm reflect the existence of the product in the same (cone) conformation. The ${ }^{1} \mathrm{H}-\mathrm{NMR}$ spectra of SGC and SCM gave two additional peaks of doublet (7.8-8.2 $\mathrm{ppm}$ ) for sulfanilamide and sulfaguanidine units. A peak around $2.5 \mathrm{ppm}$ in COX represents the methyl group of the inserted azo moiety. The MS-ESI spectra of these compounds confirmed that the insertion of azo moiety has occurred at a single position (see Supporting Information).

The tetrakis azo products of isopropyl aniline (ISO) and 3-(trifluoro)methylaniline (STF) were produced by a reported method using sodium acetate trihydrate in MeOH-DMF (5:8) An alternative method using pyridine as a medium of the reaction was also adopted (Hamon et al., 2009), however, this approach was found less suitable in term of yield and purity of products. The absence of a doublet at $\sim 7.01$ and triplet at $\sim 6.9 \mathrm{ppm}$ in
${ }^{1} \mathrm{H}-\mathrm{NMR}$ spectra of these compounds indicate that all the para positions have been occupied by azo moieties. The ${ }^{1} \mathrm{H}-\mathrm{NMR}$ spectrum of ISO (Figure 2) showed a singlet at $7.8 \mathrm{ppm}$ for the eight ortho hydrogens of calix[4]arene unit. In ${ }^{13} \mathrm{C}-\mathrm{NMR}$, the two characteristic peaks of the product at $20 \mathrm{ppm}$ and 33 ppm correspond to methyl groups and methine carbon. The IR spectrum of the compound showed two bands for $\mathrm{CH}_{3}$ and $\mathrm{CH}$ protons at 2,959 and $2,866 \mathrm{~cm}^{-1}$ respectively. In the case of STF, an additional singlet at $8.10 \mathrm{ppm}$ appeared for the four ortho hydrogens of the azo moiety.

\section{In Vitro Study}

The synthesized compounds were screened against five Grampositive bacterial strains (Bacillus subtilis, Staphylococcus aureus, Methicillin-resistant Staphylococcus aureus (MRSA), Staphylococcus epidermidis Enterococcus faecalis), two Gramnegative bacterial strains (Escherichia coli and Pseudomonas aeruginosa) and two fungal strains (Candida albicans and Saccharomyces cerevisiae). Table 1 reveals that most of the compounds showed activity only against Gram-positive strains. It may be due to the fact that Gram-negative bacteria and fungi have more complex structure than Gram-positive bacteria. The impenetrable cell membrane of Gram-negative bacteria is one of the reasons that many drugs are ineffective against these strains (Silhavy et al., 2010; Miller, 2016).

Compound SCM showed better activity among the tested compounds. It has the lowest minimum inhibitory concentration (MIC) value against MRSA $(0.97 \mu \mathrm{g} / \mathrm{mL})$ and $B$. subtilis $(0.97 \mu \mathrm{g} / \mathrm{mL})$. The reference drug, chloramphenicol gave MIC value $0.97 \mu \mathrm{g} / \mathrm{mL}$ against MRSA while that of gentamycin $(\mathbf{G})$ was found to be $>62.5 \mu \mathrm{g} / \mathrm{mL}$. The compound also showed good inhibition against $S$. aureus (MIC $3.9 \mu \mathrm{g} / \mathrm{mL}$ ), S. epidermidis

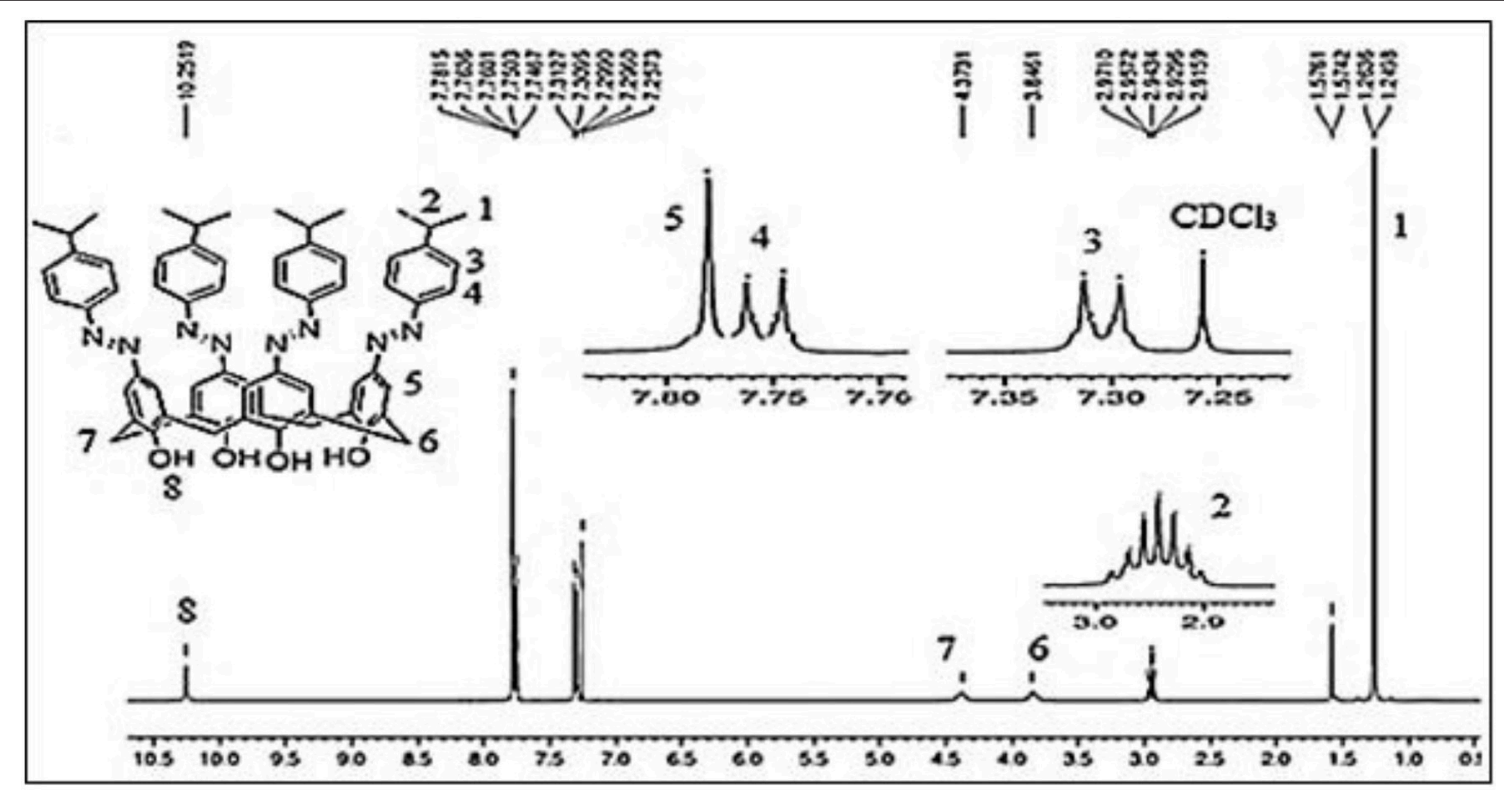

FIGURE 2 | ${ }^{1} \mathrm{H}$-NMR spectrum of compound ISO (5,11,17,23-tetrakis(4-isopropylphenyl) azo calix[4]arene). 
TABLE 1 | MIC values of synthesized compounds against selected microbial strains.

\begin{tabular}{|c|c|c|c|c|c|c|c|}
\hline Microbes & SCM MIC $(\mu \mathrm{g} / \mathrm{mL})$ & SGC MIC $(\mu \mathrm{g} / \mathrm{mL})$ & COX MIC $(\mu \mathrm{g} / \mathrm{mL})$ & SPh MIC ( $\mu \mathrm{g} / \mathrm{mL})$ & ISO MIC $(\mu \mathrm{g} / \mathrm{mL})$ & STF MIC ( $\mu \mathrm{g} / \mathrm{mL})$ & $\mathbf{R} \mathbf{D}^{\star *}$ \\
\hline S. aureus & 3.9 & 7.8 & 7.8 & $>125$ & $>125$ & $>125$ & $\mathrm{G}=3.9$ \\
\hline MRSA & 0.97 & 15.6 & 7.8 & $>125$ & 31.25 & $>125$ & $\begin{array}{l}\mathrm{Ch}=0.97 \\
G>62.5\end{array}$ \\
\hline B. subtilis & 0.97 & 15.6 & 0.97 & $>125$ & 125 & $>125$ & $G<0.5$ \\
\hline S. epidermidis & 1.9 & 7.8 & 1.9 & $>125$ & 62.5 & $>125$ & $G>31.2$ \\
\hline E. faecalis & 7.8 & 31.25 & 7.8 & $>125$ & 15.6 & $>125$ & $G>31.2$ \\
\hline E. coli & $>125$ & $>125$ & 125 & $>125$ & $>125$ & $>125$ & $G<31.2$ \\
\hline$P$. aeruginosa & $>125$ & 15.6 & 62.5 & $>125$ & 62.5 & $>125$ & $G<0.5$ \\
\hline C. albicans & $>125$ & 62.5 & $>125$ & $>125$ & $>125$ & $>125$ & Ny $<0.9$ \\
\hline S. cerevisiae & $>125$ & $>125$ & $>125$ & $>125$ & $>125$ & $>125$ & $\mathrm{Ny}<0.9$ \\
\hline
\end{tabular}

${ }^{\star \star} R D$, reference drug; G, gentamycin; Ch, chloramphenicol; Ny, nystatin.

(MIC $15.6 \mu \mathrm{g} / \mathrm{mL}$ ) and E. faecalis (MIC $3.9 \mu \mathrm{g} / \mathrm{mL}$ ). The activity of SCM may be attributed to the presence of sulfonamide unit. The antimicrobial activity of sulfonamides is due to its structural similarity with $p$-aminobenzoic acid ( $p \mathrm{ABA}$ ), which is produced by bacteria for the biosynthesis of folic acid, an essential growth factor. Sulfonamides exert antibacterial action by antagonizing pABA utilization, thus prevent the synthesis of folic acid and stop bacterial growth (Achari et al., 1997). However, compound SCM has no effect on the selected Gram-negative and fungal strains. The complex nature of the cell wall may be the possible reason for their inactivity.

Sulfaguanidine-based azo calix[4] arene (SGC) showed good inhibition against S. epidermidis, S. aureus (MIC $7.8 \mu \mathrm{g} / \mathrm{mL}$ ), MRSA and B. subtilis (MIC $15.6 \mu \mathrm{g} / \mathrm{mL}$ ). In addition, it was also active against $P$. aeruginosa (Gram-negative) at MIC $15.6 \mu \mathrm{g} / \mathrm{mL}$ and C. albicans (fungus) at MIC $62.5 \mu \mathrm{g} / \mathrm{mL}$. SGC was found to possess higher activity compared to its respective monomer, sulfaguanidine phenolic azo compound $(\mathbf{S P h})$. The ratio between the MIC of monomer (SPh) and its corresponding azo calix[4]arene (SGC) ranged from 10 to $22 \mu \mathrm{g} / \mathrm{mL}$. It indicates that the activity of SGC is due to the combined effect of guanidinium unit and macrocyclic scaffold. A similar result was published by Mourer et al. (2009), where guanidinium derivative of calix[4]arene was found to be more active than the corresponding monomer. On the same note, da Silva et al. (2016) also reported that iminecalix[4]arenes showed better inhibition potential against Candida strains than their corresponding monomers.

Azo calix[4]arene having a 2-methyl-4-aminobenzoic acid unit (COX) was expected to show better activity than others as it is showing close resemblance with $p \mathrm{ABA}$. However, there was no remarkable difference in the MIC value compared to compounds SCM and SGC. Minimum bactericidal concentration (MBC) was evaluated for B. subtilis and found to be $62.5 \mu \mathrm{g} / \mathrm{mL}$. Unlike SCM and SGC, COX did not show bactericidal activity for the rest of the strains at $62.5 \mu \mathrm{g} / \mathrm{mL}$. The antimicrobial agent is considered to be bacteriostatic when the MBC/MIC ratio is $>4$, while it is considered to be bactericidal if the $\mathrm{MBC} / \mathrm{MIC}$ ratio is $<4$ (Barry et al., 1999; Pannu et al., 2011). Only one compound (SGC)
TABLE 2 | List of binding energy (B.E.) and inhibition constant (Ki) of synthesized compounds and co-crystalized ligand(Co-lig)/OS as calculated using molecular docking.

\begin{tabular}{|c|c|c|c|c|c|c|}
\hline \multirow[t]{2}{*}{ Ligands } & \multicolumn{2}{|c|}{ 4CJN } & \multicolumn{2}{|c|}{ 1CEF } & \multicolumn{2}{|l|}{$3 T 16$} \\
\hline & $\begin{array}{c}\text { B.E. } \\
\text { (kcal/mol) }\end{array}$ & $\begin{array}{l}\mathbf{K i} \\
(\mu \mathrm{M})\end{array}$ & $\begin{array}{c}\text { B.E. } \\
\text { (kcal/mol) }\end{array}$ & $\begin{array}{c}\mathbf{K i} \\
(\mu \mathrm{M})\end{array}$ & B.E. (kcal/mol) & $\mathbf{K i}(\mu \mathbf{M})$ \\
\hline SGC & -9.54 & 0.10 & -8.18 & 1.00 & -7.07 & 6.59 \\
\hline SCM & -8.97 & 0.26 & -7.69 & 2.32 & -7.64 & 2.50 \\
\hline $\operatorname{cox}$ & -8.68 & 0.43 & -6.59 & 14.75 & -7.72 & 2.21 \\
\hline SPh & -6.75 & 11.33 & -6.52 & 16.55 & -5.3 & 52 \\
\hline ISO & -8.54 & 0.54 & -6.67 & 12.83 & -5.70 & 66.68 \\
\hline STF & -8.00 & 1.36 & -4.44 & 559.93 & -6.41 & 19.92 \\
\hline Co-lig & -8.94 & 0.28 & -7.06 & 6.72 & - & - \\
\hline os & - & - & - & - & -7.78 & 1.98 \\
\hline
\end{tabular}

exhibited bactericidal activity against $B$. subtilis $(\mathrm{MBC} / \mathrm{MIC}=2)$. The rest of the compounds did not show bactericidal activity against any species.

The tetrakis azo products (ISO and STF) have limited inhibitory activity. The MBC values for these two compounds were not determined because of their high MIC values. Compound ISO showed moderate activity against S. epidermidis and E. faecalis at MIC $62.5 \mu \mathrm{g} / \mathrm{mL}$ and $15.6 \mu \mathrm{g} / \mathrm{mL}$, respectively. In addition, it showed similar effect like compound COX against $P$. aeruginosa with MIC value $62.5 \mu \mathrm{g} / \mathrm{mL}$.

\section{In Silico Study}

The synthesized azo calix[4]arenes were docked against two receptors of penicillin-binding proteins (PDB IDs: 4CJN, 1CEF) and one receptor of the viral enzyme, neuraminidase, (PDB ID: 3TI6). Penicillin-binding proteins (PBPs) are the extracellular membrane-bound enzymes found in bacteria while absent in mammalian cells (Gullo, 1994; Onoabedje et al., 2016). Inhibition of PBPs causes structural abnormalities of a bacterial cell that result in cell death and lysis and, therefore, PBPs act as validated targets for antibacterial therapy. Neuraminidase is a glycoside hydrolase enzyme required for the viral replication (Chen et al., 


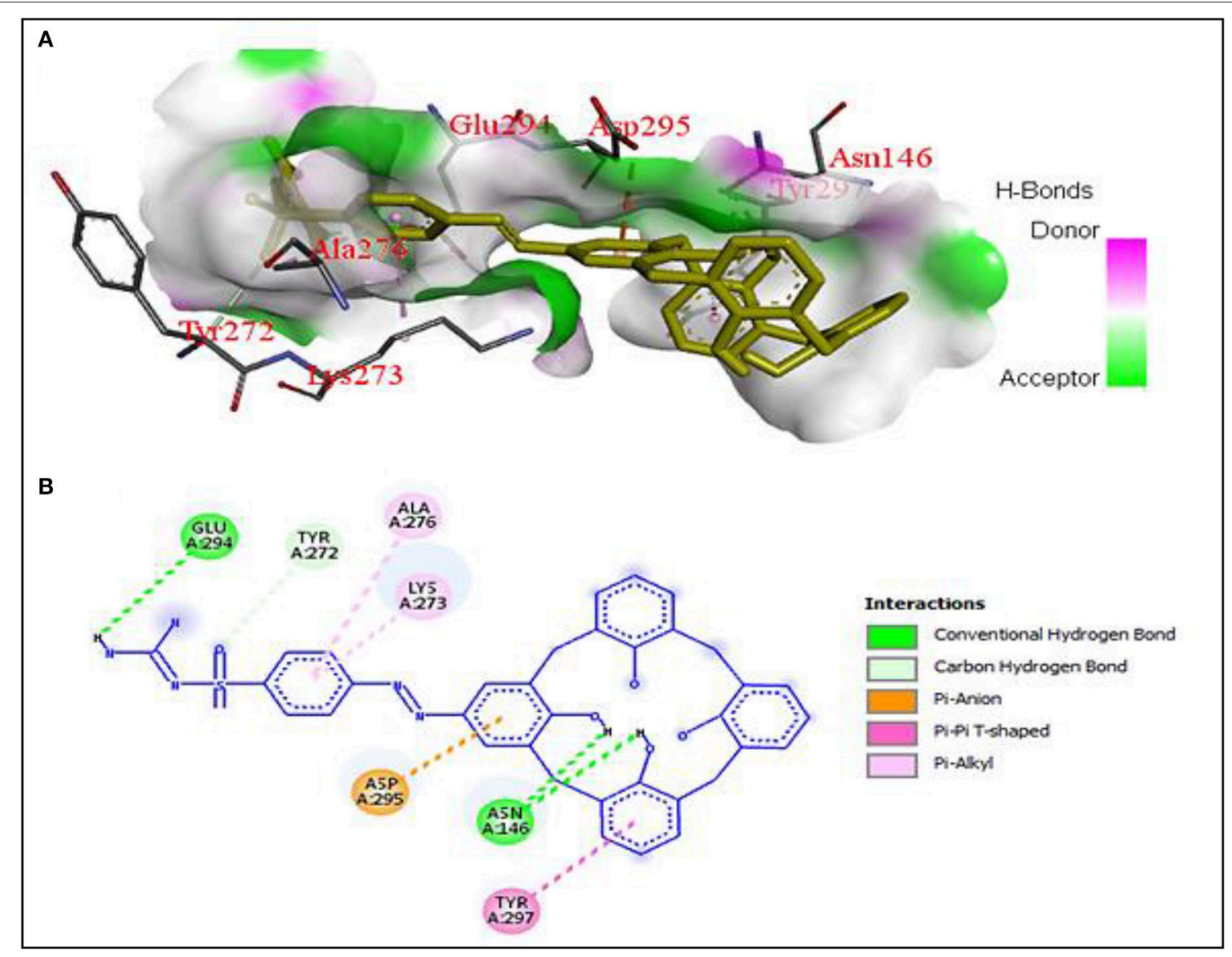

FIGURE 3 | (A) Hydrogen bonding interactions between 4CJN and SGC residues with binding affinity of $-9.54 \mathrm{kcal} / \mathrm{mol}$, (B) $2 \mathrm{D}$ diagram of SGC interaction with 4 CJN.

2016). Neuraminidase inhibitors are designed to restrain the release of the influenza virus from the infected host cells (Hariono et al., 2016).

The values of binding energy (B.E.) and an inhibition constant of the synthesized compounds are given in Table 2. The co-crystalized ligands (Co-lig), 4CJN and 1CEF were re-docked in the active sites of their respective receptors and the results were taken as reference for the subsequent docking of the synthesized compounds. In the case of 3TI6, the binding affinity of azo calix[4] arenes was compared with a standard drug, oseltamivir (OS). Compounds containing sulfonamide group (SGC and SCM) showed more affinity toward $4 \mathrm{CJN}$. The strongest interaction was shown by sulfaguanidinebased azo calix[4]arene (SGC) with a binding affinity of 9.54 $\mathrm{kcal} / \mathrm{mol}$ and $\mathrm{Ki}$ value $0.10 \mu \mathrm{M}$ which is 2.8 times stronger than the co-crystallized ligand. In general, drugs that show $\mathrm{Ki}$ value $<1 \mathrm{mM}$ are considered to be effective agents(Karimi, 2014). Hydrogen bond interaction was observed between the phenolic hydroxyl group of calix[4]arene unit and Asn146. A second hydrogen bond is formed by guanidinium part with Glu294. Lys273, which has been reported as the key residue in the active site of $4 \mathrm{CJN}$, showed hydrophobic interaction with the aromatic ring of sulfaguanidine moiety (de Araújo et al., 2016) (Figure 3). SCM showed comparable result with the co-crystallized ligand with binding energy $-8.97 \mathrm{kcal} / \mathrm{mol}$ and $\mathrm{Ki}$ value $0.26 \mu \mathrm{M}$, followed by $\mathrm{COX}$ $(-8.68 \mathrm{kcal} / \mathrm{mol})$, ISO $(-8.54 \mathrm{kcal} / \mathrm{mol})$ and STF $(-8.00$ $\mathrm{kcal} / \mathrm{mol})$.

Compounds containing sulphonamide group (SGC and SCM) also showed better interaction with 1CEF. The binding energy for SGC was found to be $-8.18 \mathrm{kcal} / \mathrm{mol}(\mathrm{Ki}=1.00 \mu \mathrm{M})$ followed by SCM with binding energy $-7.69 \mathrm{kcal} / \mathrm{mol}(\mathrm{Ki}=2.32 \mu \mathrm{M})$. The corresponding co-crystallized ligand has B.E. $-7.06 \mathrm{kcal} / \mathrm{mol}$ and Ki $6.72 \mu \mathrm{M}$. In contrast with 4CJN, COX has low affinity and gave higher binding energy with $1 \mathrm{CEF}$. The respective azo monomer of sulfaguanidine ( $\mathbf{S P h}$ ) has binding energy of $-6.75 \mathrm{kcal} / \mathrm{mol}$ $(\mathrm{Ki}=11.33 \mu \mathrm{M})$ and $-6.52 \mathrm{kcal} / \mathrm{mol}(\mathrm{Ki}=16.55 \mu \mathrm{M})$ with $4 \mathrm{CJN}$ and $1 \mathrm{CEF}$, respectively. The results are in accordance with in vitro study where SGC showed higher antimicrobial activity than SPh.

Antiviral activity of these compounds was evaluated by docking the synthesized azo calix[4]arenes against neuraminidase receptor (PDB ID: 3TI6) and four compounds showed comparable results with oseltamivir (OS), a standard drug used as neuraminidase inhibitor. The interactions of the two most active compounds compared to OS are given in Figure 4. Compound COX showed the highest affinity 

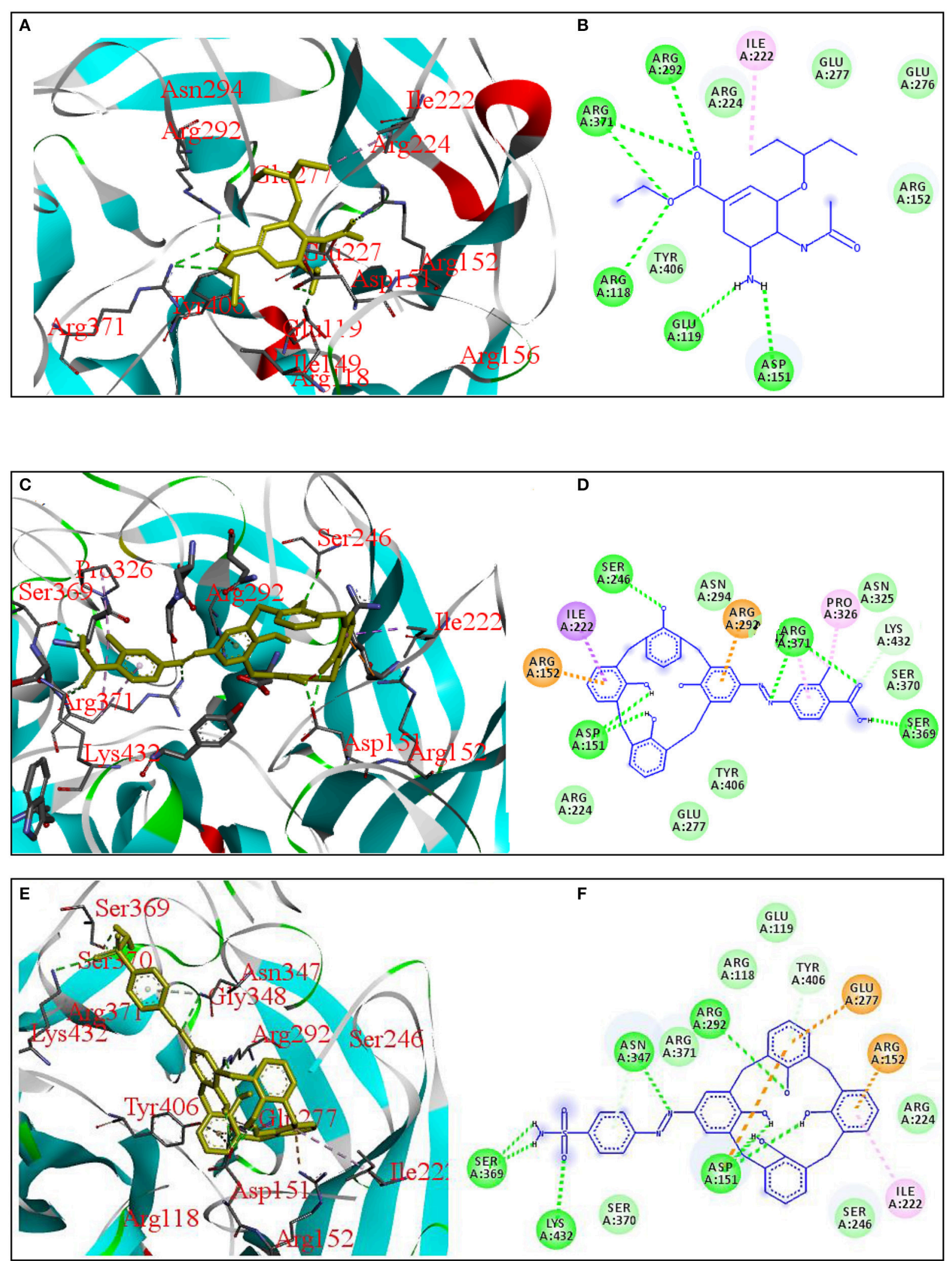

FIGURE 4 | 3D and 2D diagrams showing interactions of neuraminidase receptor (PDB ID: 3TI6) with OS (A,B), COX (C,D), and SCM (E,F), respectively. 
with B.E $-7.72 \mathrm{kcal} / \mathrm{mol}$ that is close to the OS $(\mathrm{B} . \mathrm{E}=-7.78$ $\mathrm{kcal} / \mathrm{mol}$ ). The compound fitted well into the binding pocket, forming hydrophobic as well as hydrogen bonding interactions with Arg150, Ile22, Arg292, Ser246, Ser369, and Asp151. Sulfanilamide-based azo calix[4] arene (SCM) also showed good interaction with 3 TI6 with a binding affinity of $-7.64 \mathrm{kcal} / \mathrm{mol}$ and $\mathrm{Ki}$ value of $2.50 \mu \mathrm{M}$, followed by SGC with a binding affinity of $-7.07 \mathrm{kcal} / \mathrm{mol}$. The amino acid residues involved in the interactions with SCM include Arg292, Asp 151, and Ile222.

\section{CONCLUSION}

Appropriate experimental conditions facilitated the synthesis of mono-substituted azo calix[4]arenes in good yield. The antimicrobial assay revealed that the compounds obtained from sulphanilamide, sulfaguanidine and 2-methyl-4-aminobenzoic acid showed bacteriostatic and/or bactericidal activity against B. subtilis, MRSA S. aureus, S. epidermidis and E. faecalis with MIC values ranging from 0.97 to $62.5 \mu \mathrm{g} / \mathrm{mL}$. It suggests that azo derivatives of calix[4] arene synthesized from therapeutic agents have better antimicrobial activity compared to the parent compound. Molecular docking study against the selected microbial enzymes showed good interaction with the active site residues through hydrogen, hydrophobic and pi-pi interactions and could inhibit the activity of these enzymes. The high binding affinity of sulfaguanidine and sulphanilamide-based azo calix[4]arenes toward the targeted receptors correlates with antimicrobial assay results. The positive aspect of these results is the activity of some azo calix[4]arenes against

\section{REFERENCES}

Achari, A., Somers, D. O., Champness, J. N., Bryant, P. K., Rosemond, J., and Stammers, D. K. (1997). Crystal structure of the anti-bacterial sulfonamide drug target dihydropteroate synthase. Nat. Struct. Mol. Biol. 4, 490-497. doi: 10.1038/nsb0697-490

Balouiri, M., Sadiki, M., and Ibnsouda, S. K. (2016). Methods for in vitro evaluating antimicrobial activity: a review. J. Pharmaceut. Anal. 6, 71-79. doi: 10.1016/j.jpha.2015.11.005

Barry, A. L., Craig, W. A., Nadler, H., Reller, L. B., Sanders, C. C., and Swenson, J. M. (1999). Methods for determining bactericidal activity of antimicrobial agents: approved guideline. NCCLS Document M26-A 19.

Chawla, H. M., Singh, S. P., and Upreti, S. (2006). Synthesis of cesium selective pyridyl azocalix [n] arenes. Tetrahedron 62, 2901-2911. doi: 10.1016/j.tet.2006.01.022

Chen, B. L., Wang, Y. J., Guo, H., and Zeng, G. Y. (2016). Design, synthesis, and biological evaluation of crenatoside analogues as novel influenza neuraminidase inhibitors. Eur. J. Med. Chem. 109, 199-205. doi: 10.1016/j.ejmech.2015.12.031

da Silva, C. M., da Silva, D. L., Magalhães, T. F., Alves, R. B., de Resende-Stoianoff, M. A., Martins, F. T., et al. (2016). Iminecalix [4] arenes: microwave-assisted synthesis, X-ray crystal structures, and anticandidal activity. Arab. J. Chem. doi: 10.1016/j.arabjc.2016.06.013. [Epub ahead of print].

de Araújo, R. S. A., Barbosa-Filho, J. M., Scotti, M. T., Scotti, L., Cruz, R. M., Falcão-Silva Vdos, S., et al. (2016). Modulation of drug resistance in staphylococcus aureus with coumarin derivatives. Scientifica (Cairo) 2016. doi: 10.1155/2016/6894758

Deligöz, H., and Ercan, N. (2002). The synthesis of some new derivatives of calix [4] arene containing azo groups. Tetrahedron 58, 2881-2884. doi: 10.1016/S0040-4020(02)00156-4 the multidrug-resistant Staphylococcus aureus. However, the compounds showed low to no activity against Gram-negative and fungal strains. The area is still new and more basic and mechanistic studies are needed to explore and extend the biomedical applications of azo calixarenes, from therapeutic agents to drug carriers. Suitable functionalization and insertion of therapeutic moieties on the basic scaffold of calixarene may further enhance their bioactivity.

\section{AUTHOR CONTRIBUTIONS}

SA: supervised the research project; YA: synthesized the compounds and performed modeling and in vitro study; AM: assisted in molecular docking; NM and DS: provided technical support.

\section{FUNDING}

We gratefully acknowledge the Malaysian Ministry of Science, Technology and Innovation (MOSTI) for EScience Grant no. 0601-08-SF0147 and Ministry of Higher Education (MOHE) for ERGS Grant no. ERGS12-017-0017 for financial support of this work.

\section{SUPPLEMENTARY MATERIAL}

The Supplementary Material for this article can be found online at: https://www.frontiersin.org/articles/10.3389/fchem. 2018.00210/full\#supplementary-material

Deska, M., Dondela, B., and Sliwa, W. (2015). Selected applications of calixarene derivatives. ARKIVOC 6, 393-416. doi: 10.3998/ark.5550190.p008.958

Elçin, S., Deligöz, H., Bhatti, A. A., Oguz, M., Karakurt, S., and Yilmaz, M. (2016). Synthesis and evaluation of fluorescence properties of $\mathrm{Cu} 2+$ selective azocalix [4] arenes and their application in living cell imaging. Sens. Actuat. B Chem. 234, 345-352. doi: 10.1016/j.snb.2016.04.155

Elçin, S., Ilhan, M. M., and Deligöz, H. (2013). Synthesis and spectral characterization of azo dyes derived from calix [4] arene and their application in dyeing of fibers. J. Incl. Phenom. Macrocycl. Chem. 77, 259-267. doi: 10.1007/s10847-012-0240-7

Groenen, L. C., Ruel, B. H., Casnati, A., Verboom, W., Pochini, A., Ungaro, R., et al. (1991). Synthesis of monoalkylated calix [4] arenes via direct alkylation. Tetrahedron 47, 8379-8384. doi: 10.1016/S0040-4020(01)96179-4

Gulcan, M., Özdemir, S., Dündar, A., Ispir, E., and Kurtoglu, M. (2014). Mononuclear complexes based on pyrimidine ring azo schiff-base ligand: synthesis, characterization, antioxidant, antibacterial, and thermal investigations. Zeitschrift für Anorganische Und Allgemeine Chemie 640, 1754-1762. doi: 10.1002/zaac.201400078

Gullo, V. P. (1994). Discovery of Novel Natural Products with Therapeutic Potential. Boston, MA: Butterworth-Heinemann.

Gutsche, C. D., Levine, J. A., and Sujeeth, P. D. (1985). Calixarenes. 17. Functionalized calixarenes: the Claisen rearrangement route. J. Organ. Chem. 50, 5802-5806. doi: 10.1007/978-3-642-70108-5_9

Gutsche, C., and Iqbal, M. (1990). p-tert-Butylcalix [4] arene. Organ. Synth. 68, 234-234.

Hamon, F., Djedaini-Pilard, F., Barbot, F., and Len, C. (2009). Azobenzenessynthesis and carbohydrate applications. Tetrahedron 65, 10105-10123. doi: $10.1016 /$ j.tet.2009.08.063

Hariono, M., Abdullah, N., Damodaran, K. V., Kamarulzaman, E. E., Mohamed, N., Hassan, S. S., et al. (2016). Potential new H1N1 neuraminidase inhibitors 
from ferulic acid and vanillin: molecular modelling, synthesis and in vitro assay. Sci. Rep. 6:38692. doi: 10.1038/srep38692

Jin, C. M., Lu, G. Y., Liu, Y., You, X. Z., Wang, Z. H., and Wu, H. M. (2002). Synthesis of (p-Substituted phenyl) azo Calix [4] arenes. Chin. J. Chem. 20, 1080-1087. doi: $10.1002 /$ cjoc.20020201029

Karakuş, Ö. Ö., and Deligöz, H. (2015). Synthesis, extraction and chromogenic properties of Amidoazocalix [4] arenes and their telomer derivatives. Supramol. Chem. 27, 110-122. doi: 10.1080/10610278.2014. 910603

Karimi, R. (2014). Biomedical \& Pharmaceutical Sciences with Patient Care Correlations. Burlington: Jones \& Bartlett Publishers.

Miller, S. I. (2016). Antibiotic resistance and regulation of the gram-negative bacterial outer membrane barrier by host innate immune molecules. MBio 7 , e01541-e01516. doi: 10.1128/mBio.01541-16

Mkpenie, V., Ebong, G., Obot, I., and Abasiekong, B. (2008). Evaluation of the effect of azo group on the biological activity of 1-(4methylphenylazo)-2-naphthol. J. Chem. 5, 431-434. doi: 10.1155/2008/ 438946

Mo, J., Eggers, P. K., Yuan, Z. X., Raston, C. L., and Lim, L. Y. (2016). Paclitaxelloaded phosphonated calixarene nanovesicles as a modular drug delivery platform. Sci. Rep. 6:23489. doi: 10.1038/srep23489

Morita, Y., Agawa, T., Nomura, E., and Taniguchi, H. (1992). Syntheses and NMR behavior of calix [4] quinone and calix [4] hydroquinone. J. Org. Chem. 57, 3658-3662. doi: 10.1021/jo00039a027

Mourer, M., Dibama, H. M., Fontanay, S., Grare, M., Duval, R. E., Finance, C., et al. (2009). p-Guanidinoethyl calixarene and parent phenol derivatives exhibiting antibacterial activities. Synthesis and biological evaluation. Bioorgan. Med. Chem. 17, 5496-5509. doi: 10.1016/j.bmc.2009. 06.040

Nimse, S. B., and Kim, T. (2013). Biological applications of functionalized calixarenes. Chem. Soc. Rev. 42, 366-386. doi: 10.1039/C2CS3 $5233 \mathrm{H}$

Onoabedje, E. A., Ibezim, A., Okafor, S. N., Onoabedje, U. S., and Okoro, U. C. (2016). Oxazin-5-ones as a novel class of penicillin binding protein inhibitors: design, synthesis and structure activity relationship. PLOS ONE 11:e0163467. doi: 10.1371/journal.pone.0163467

Pannu, J., McCarthy, A., Martin, A., Hamouda, T., Ciotti, S., Ma, L., et al. (2011). In vitro antibacterial activity of NB-003 against Propionibacterium acnes. Antimicrob. Agents Chemother. 55, 4211-4217. doi: 10.1128/AAC. 00561-11

Ramanjaneyulu, P. S., Singh, P., Sayi, Y. S., Chawla, H. M., and Ramakumar, K. L. (2010). Ion selective electrode for cesium based on 5-(4'-nitrophenylazo) 25 , 27-bis (2-propyloxy) 26, 28-dihydroxycalix [4] arene. J. Hazard. Mater. 175, 1031-1036. doi: 10.1016/j.jhazmat.2009.10.113
Rizk, H., Ibrahim, S., and El-Borai, M. (2015). Synthesis, fastness properties, color assessment and antimicrobial activity of some azo reactive dyes having pyrazole moiety. Dyes Pigments 112, 86-92. doi: 10.1016/j.dyepig.2014.06.026

Sahoo, J., Mekap, S. K., and Kumar, P. S. (2015). Synthesis, spectral characterization of some new 3-Heteroaryl azo 4-Hydroxy coumarin derivatives and their antimicrobial evaluation. J. Taibah Univ. Sci. 9, 187-195. doi: 10.1016/j.jtusci.2014.08.001

Schneider, G. (2000-2013). "Prediction of drug-like properties," in Madame Curie Bioscience Database [Internet] (Austin, TX: Landes Bioscience).

Shaikh, A., and Meshram, J. S. (2015). Design, synthesis and pharmacological assay of novel azo derivatives of dihydropyrimidinones. Cogent Chem. 1:1019809. doi: 10.1080/23312009.2015.1019809

Shinkai, S. (1993). Calixarenes-the third generation of supramolecules. Tetrahedron 49, 8933-8968. doi: 10.1016/S0040-4020(01)91215-3

Silhavy, T. J., Kahne, D., and Walker, S. (2010). The bacterial cell envelope. Cold Spring Harb. Perspect. Biol. 2:a000414. doi: 10.1101/cshperspect.a000414

Sliwa, W., and Deska, M. (2011). Functionalization reactions of calixarenes. ARKIVOC 1, 496-551. doi: 10.3998/ark.5550190.0012.110

Tang, J., Sun, Y., Li, L., Xu, Z., and Lv, Z. (2015). "Research on synthesis of new azo calix [4] arene and its dyeing properties," in 2015 International Conference on Energy, Materials and Manufacturing Engineering (EMME 2015), Vol. 25 (Les Ulis: EDP Sciences), p. 02016.

Tauran, Y., Coleman, A., Perret, F., and Kim, B. (2015). Cellular and in vivo biological activities of the calix [n] arenes. Curr. Org. Chem. 19, 2250-2270. doi: 10.2174/1385272819666150608222114

Vicens, J., and Böhmer, V. (2012). Calixarenes: A Versatile Class of Macrocyclic Compounds. Dordrecht; Boston, MA; London: Kluwer Academic Publishers.

Vicens, J., Harrowfield, J., and Baklouti, L. (2007). Calixarenes in the Nanoworld. Dordrecht: Springer.

Yousaf, A., Hamid, S. A., Bunnori, N. M., and Ishola, A. (2015). Applications of calixarenes in cancer chemotherapy: facts and perspectives. Drug Des. Devel. Ther. 9, 2831-2838. doi: 10.2147/DDDT.S83213

Conflict of Interest Statement: The authors declare that the research was conducted in the absence of any commercial or financial relationships that could be construed as a potential conflict of interest.

Copyright (๑) 2018 Ali, Muhamad Bunnori, Susanti, Muhammad Alhassan and Abd Hamid. This is an open-access article distributed under the terms of the Creative Commons Attribution License (CC BY). The use, distribution or reproduction in other forums is permitted, provided the original author(s) and the copyright owner are credited and that the original publication in this journal is cited, in accordance with accepted academic practice. No use, distribution or reproduction is permitted which does not comply with these terms. 